\title{
Beta-lactam hypersensitivity: not always what it seems
}

\author{
Djanira Andrade ${ }^{1 *}$, Katia Jojima', Alex Lacerda ${ }^{1}$, Ligia Maria Oliveira Machado ${ }^{1}$, Luis Felipe Ensina', \\ Inês Cristina Camelo Nunes ${ }^{1}$, Dirceu Sole ${ }^{2}$ \\ From 3rd WAO International Scientific Conference (WISC) 2014 \\ Rio de Janeiro, Brazil. 6-9 December 2014
}

\section{Background}

Beta-lactam allergy is a frequent cause of visit to the allergist office. The aim of this study was to describe the characteristics of children with a suspected beta-lactam hypersensitivity reaction in a specialized drug allergy unit.

\section{Methods}

Retrospective analysis based on medical records using an adapted ENDA questionnaire of patients under 18 years old from July 2011 to June 2014 .

\section{Results}

One hundred and four children were evaluated with a suspected drug allergy history, with $28 \%$ reporting reactions to beta-lactam antibiotics. The mean age was 6.2 years and $52 \%$ were female. Cutaneous symptoms were the most frequent reported (89\%), followed by respiratory $(45 \%)$. Most of them had maculopapular exanthema (52\%). Urticaria and/or angioedema were seen in $34 \%$ of patients. The majority of the reactions were mild/moderate (93\%), occurring in the first 24 hours after drug intake (77\%), and $48 \%$ presented associated fever. The suspected drugs were: amoxicilin $(59 \%)$, cefalexin $(16 \%)$, penicilin and ceftriaxone $(8 \%$ each). Patients went to an Emergency Unit in $97 \%$ of the reactions and treated with anti-histaminic drugs and corticosteroids in $40 \%$ and $30 \%$ respectively. Epinephrine was used in just one patient. In almost half of the patients the clinical history was not consistent enough to submit them to an extensive investigation. Of those who were investigated, skin tests were performed in $48 \%$ (57\% prick tests and $43 \%$ intradermal tests). Positive test

${ }^{1}$ Federal Universtity of Sao Paulo, Brazil

Full list of author information is available at the end of the article was seen in only one patient (cefazolin). Drug provocation tests with amoxicilin were performed in $57 \%$ of patients and none was positive.

\section{Conclusions}

The prevalence of children with a beta-lactam hypersensitivity history is high, but a few cases are confirmed as allergic after an adequate investigation.

\section{Authors' details}

${ }^{1}$ Federal Universtity of Sao Paulo, Brazil. ${ }^{2}$ Brazilian Society, Brazil.

Published: 8 April 2015

doi:10.1186/1939-4551-8-S1-A168

Cite this article as: Andrade et al.: Beta-lactam hypersensitivity: not always what it seems. World Allergy Organization Journal 2015 8(Suppl 1): A168.
Submit your next manuscript to BioMed Central and take full advantage of:

- Convenient online submission

- Thorough peer review

- No space constraints or color figure charges

- Immediate publication on acceptance

- Inclusion in PubMed, CAS, Scopus and Google Scholar

- Research which is freely available for redistribution

Submit your manuscript at www.biomedcentral.com/submit
() Biomed Central 